\title{
English in Russia: To Learn or Not To Learn - That Is the Question
}

\author{
Tatiana Aleksandrovna Legasova ${ }^{1}$ \\ ${ }^{1}$ Lobachevsky State University of Nizhni Novgorod - National Research University, Nizhny Novgorod, Russia \\ Correspondence: Tatiana Aleksandrovna Legasova, Lobachevsky State University of Nizhni Novgorod - \\ National Research University, 603950, Gagarin Avenue, 23, Nizhny Novgorod, Russia. E-mail: pr@unn.ru
}

\author{
Received: July 30, 2014 Accepted: September 30, 2014 Online Published: December 30, 2014 \\ doi:10.5539/ass.v11n3p231 URL: http://dx.doi.org/10.5539/ass.v11n3p231
}

\begin{abstract}
This article explores the issues of the English language position in Russia. In recent years English has emerged as the pre-eminent language for international communication all over the globe. It is spoken by more people around the world than any other language, and is regularly described as a truly 'global' language. The author claims that the position of English in Russia is not that striking as in the whole world. It is mostly connected with the geographical position of this huge country/ Russia is the largest country in the world, covering more than one-eighth of the Earth's inhabited land area. Russia is also the world's ninth most populous nation with 143 million people as of 2012. Extending across the entirety of northern Asia and much of Eastern Europe, Russia spans nine time zones and incorporates a wide range of environments and landforms. The author comes to the conclusion that only the center of Russia (such cities as Moscow, Saint Petersburg, Nizhny Novgorod, Yekaterinburg) exhibits the special role of English for most of the population due to the international companies that are mostly located there and offer jobs for people, the most outstanding Universities that invite students from abroad and international affairs that huge Russian companies accumulated in the above mentioned cities have with their foreign partners.
\end{abstract}

Keywords: English in Russia, ELF, lingua franca, global communication

\section{Introduction}

I have been working at the Lobachevsky State University of Nizhny Novgorod for four years and every day I see how my students recognize the importance of the English language in today's globalized world but still don't have enough motivation to learn it. Let's consider the question of the importance of mastering the English language in Russia.

It's generally acknowledged that English is the most commonly used language among foreign language speakers. Throughout the world, when people with different languages come together they commonly use English to communicate. It's admitted to be lingua franca (ELF) - the term refers to the teaching, learning, and use of the English language as a common means of communication for speakers of different native languages (Seidlhofer, 2005). English will put you in touch with more people than any other languages. It is commonly spoken throughout much of the world due to Great Britian's expansion during the colonial age. People in Australia, New Zealand, Canada, parts of Africa, India, and many smaller island nations speak English. English is the commonly adopted second language in Germany, Norway, Sweden, Denmark and the Netherlands (Crystal, 2003). Speaking English opens these countries and cultures up to people who speak it. The status of English is such that it has been adopted as the world's lingua franca for communication in Olympic sport, international trade, and air-traffic control. Unlike any other language, past or present, English has spread to all five continents and has become a truly global language (Sung, 2014).

\section{Materials and Methods}

In Russia English is also very popular but unfortunately not throughout the whole country. Moscow and Saint-Petersburg are almost the only cities where English can make you employable, open your job prospects and increase your standard of living. There are many international companies there that need bilingual employees. The ability to speak English well is one of the most important things that newcomers need to gain employment. Those with strong English skills will become employable much faster than those who have only basic English skills. But in other Russian cities English is not that popular and called-for. However it should be 
observed that there is a wraparound tendency to demand from the workers fluency in English even if the work is hardly going to be connected with the language.

One more point that stands for English in Russia is that Russian universities offer a growing number of degrees taught in English. Sergey Roshchin, vice rector of the National Research University Higher School of Economics (HSE), says the move towards more teaching in English is "absolutely logical" (Worldwide University rankings, 2014). He says that a vast majority of academic activities nowadays require some English language proficiency. "If universities strive to be the world's first-league players, they deliver courses in English and develop English language academic programs" (Research trends, 2008).

Nowadays increasing numbers of universities worldwide are trying to attract both home and international students to survive in this globalized world. Every Institution today wants to participate in the process of "internalisation" because it brings many benefits. As the world becomes more interconnected across borders, the boundaries of higher education itself expand. We attract students from all over the globe and that means more students, more money, more research, more fame.

\section{Results}

Working with international students is a challenge for the teachers all over the globe. We need bilingual teachers who not only teach languages but also deliver all the subjects in English - be it chemistry or philosophy. And in our country it is extremely difficult to find such specialists for the salaries that are proposed by the universities. The only way to satisfy the need is to gradually shift the University language from Russian into English. Of course it will take time but it will also eventually take Russia to the international educational arena.

The next point that should be stressed is that English has become a Universal language of science. Since the end of the Second World War, English has become the established language of scholarly communication (Research trends, 2012). For example, roughly $80 \%$ of all the journals indexed in Scopus are published in English (Besnier, 2013). This fact is extremely beneficial for the scientists from the point of view of the access. By learning a single language, scientists around the world gained access to the vast scientific literature and can communicate with other scientists anywhere in the world. Communicative competence now requires English knowledge (Jenkins, 2006).

What's more there are some academic disciplines that demand at least English reading skills. I always say that to my PR students. Public Relations was born in America and its most important organizations are located in English speaking countries. All the articles and materials, the latest breakthroughs and PR trends are on the Internet in English. So if you want to become a veteran PR worker you must know English!

The last but not the least is of course traveling. If we want to enrich our life we should travel. And it is much more comfortable to travel when you possess language speaking skills. In recent years English for tourism has become very popular in Russia. But unfortunately these studies come to its end very fast in most cases because travelling is not a powerful motivation that can encourage people master a language. Tourists usually get satisfied with learning some English basics without going deeper. Only those who want to study abroad take their English classes seriously.

\section{Discussion}

It goes without saying that English is the language of globalization. Today the number of non-native speakers at least four times exceeds the number of native speakers (House, 2010). We can state that English is no longer used to communicate with native speakers only. English is a medium of communication and is widely used as lingua franca (Jenkins, 2009). The use of the English language have expanded to cover almost all spheres of our life from the language of business and international relations to the language of science; from the language of aviation to the language of tourism and popular culture.

In Russia English is the only language that at least potentially can claim to be the second language (Avralev \& Efimova, 2013). There are no other popular second languages in the country that seem to be embedded in Russia's almost monolingual languages habitats. Of course there are thirty five different languages in Russia which are considered official languages in various regions of the country, along with Russian and there are over one hundred minority languages spoken in Russia today. But Russian is the only official language (Chuprunov et al., 2010). There are also some historical connections with German but only few people know German in Russia and use it mostly in business. 


\section{Conclusion}

To conclude it should be stated that English has squeezed out every other language in the competition to become the common language of the world (Rubdy \& Saraceni, 2006). It has occupied such important domains like science, The Internet, diplomacy, the media, the educational system (Klimpfinger, 2009). It has also become very important in Russia but its position is not equally strong in all parts of this tremendous country. Only the center of Russia and the territories close to foreign borders can pretend to have a special role of the English language there (Grudzinskiy, 2004). Because of the Russia's geographical peculiarities English plays a bit lesser role than for example in Europe. Only highly-educated Russian people are bilingual with English as the second language. English has become a worldwide phenomenon and more than eighty per cent of interaction in the world is in English. So Russia needs to teach highly-qualified specialists or invite them from abroad to teach English in the country. It is extremely important to be the part of international English speaking society. English is today considered the language of international workplace communication. English as a lingua franca has become increasingly adopted both for internal and external communications all over the globe (Mauranen, 2009), not only in business but also in international organizations. Russia plays a very important role on the international arena that is why the government should pay more attention to the English language teaching.

\section{References}

Avralev, N., \& Efimova, I. (2013). University Rankings as a Tool to Enhance Competitiveness, Clustering and Transnational Governance of Higher Education in the Context of Globalization. Middle-East Journal of Scientific Research, 16(3), 357-361.

Barbara, S. (2005). English as a lingua franca. ELT Journal, 59(4). Retrieved October 7, 2014, from http://eltj.oxfordjournals.org/content/59/4/339.full.pdf

Besnier, N. (2013). Language on the edge of the global: Communicative competence, agency, and the complexity of the local. Language and Communication, 33(4), 463-471. http://dx.doi.org/10.1016/j.langcom. 2013.02.002

Chuprunov, E. V., Gurbatov, S. N., \& Bednyy, B. I. (2010). Comprehensive Research University in the Innovative Knowledge Society. University Management: Practice and Analysis, 1, 6-16.

Crystal, D. (2003). English as a global language (p. 4). Cambridge University Press. http://dx.doi.org/10.1017/ CBO9780511486999

English as the International Language of Science. (2008, July). Research trends, (6). Retrieved October 1, 2014, from http://www.researchtrends.com/issue6-july-2008/english-as-the-international-language-of-science

Grudzinskiy, A. O. (2004). Project-oriented university: Professional entrepreneurial organization of the university (pp. 7-14). UNN Press.

House, J. (2010). The Pragmatics of English as a lingua franca. In A. Trosborg, (Ed.), Pragmatics across languages and cultures (pp. 363-387).

Jenkins, J. (2006). Current perspectives on teaching world Englishes and English as a lingua franca. TESOL Quarterly, 40(1), 157-181. http://dx.doi.org/10.2307/40264515

Jenkins, J. (2009). English as a lingua franca: Interpretations and attitudes. World Englishes, 28(2), 200-207. http://dx.doi.org/10.1111/j.1467-971X.2009.01582.x

Klimpfinger, T. (2009). 'She's mixing the two languages together' - Forms and Functions of Code-Switching in English as a Lingua Franca. In A. Mauranen, \& E. Ranta (Eds.), English as a Lingua Franca: Studies and Findings (pp. 348-371). Cambridge: Cambridge Scholars Publishing.

Rubdy, R., \& Saraceni, M. (Eds.). (2006). English in the world: global rules, global roles (pp. 40-50). London: Continuum.

Study in English in Russia. QS Top Universities - worldwide University rankings, guides and events. Retrieved September 12, 2014, from http://www.topuniversities.com/where-to-study/europe/russia/study-english -russia

Sung, C., \& Cheung, M. (2014). English as a lingua franca and global identities: Perspectives from four second language learners of English in Hong Kong. Linguistics and Education, 26, 31-39. http://dx.doi.org/10.1016/j.linged.2014.01.010

The Language of (Future) Scientific Communication. (2012, November). Research trends, (31). Retrieved September 12, 2014, from http://www.researchtrends.com/issue-31-november-2012/the-language-of-future- 
scientific-communication/

\section{Copyrights}

Copyright for this article is retained by the author(s), with first publication rights granted to the journal.

This is an open-access article distributed under the terms and conditions of the Creative Commons Attribution license (http://creativecommons.org/licenses/by/3.0/). 